\title{
Factors that Affect User Satisfaction of Dukcapil Application (Dukcapil Dalam Genggaman) in Surakarta Regency
}

\author{
Andreas Bayu Darmawan', Rino Ardhian Nugroho² \\ ${ }^{1}$ Program Studi Ilmu Administrasi Negara, Universitas Sebelas Maret, Indonesia. \\ E-mail: andreasbayudarmawan@student.uns.ac.id \\ 2Program Studi Ilmu Administrasi Negara, Universitas Sebelas Maret, Indonesia. \\ E-mail: rino.nugroho@staff.uns.ac.id
}

\section{ARTICLE INFO}

Keywords: Dukcapil application, EUCS, eGovernment, User Satisfaction

Kata kunci: Dukcapil Dalam Genggaman, EUCS, e-Government, Kepuasan Pengguna

How to cite:

Darmawan, A. B., $\mathcal{E}$ Nugroho, R. A. (2020). Factors that Affect User Satisfaction of Dukcapil Application (Dukcapil Dalam Genggaman) in Surakarta Regency. JAKPP (Jurnal Analisis Kebijakan dan Pelayanan Publik, 6(2), 154-175.

\section{ABSTRACT}

Electronic Government (e-Government) has been implemented in Indonesia at both the central and regional levels, where Information and Communication Technology (ICT) is integrated with public services in order to increase effectiveness, efficiency, and transparency. Surakarta has succeeded in creating an application that operates online which can be used to access population administration services, namely Dukcapil application (Dukcapil dalam genggaman in Indonesian term). This application is designed to make it easier for some people of Surakarta who are still experiencing problems if they have to directly access population administration services, whether constrained in terms of time, energy, and cost. As part of population administration services and population information systems, user satisfaction is important for Dukcapil Dalam Genggaman because it is related to the quality of the services provided and the success of implementing the application. User satisfaction can be influenced by several factors. Therefore, this study will examine the factors that influence user satisfaction of Dukcapil Dalam Genggaman. These factors were adapted from a model for measuring the level of user satisfaction with information systems, namely End User Computing Satisfaction (EUCS), which measures satisfaction based on content, accuracy, format, ease of use, and timeliness. This study aims to determine the effect of these factors on user satisfaction of Dukcapil Dalam Genggaman. The questionnaire was distributed to users of Dukcapil Dalam Genggaman and successfully obtained a sample of 107 users. The data analysis used is multiple linear regression. It was found that content, accuracy, ease of use, and timeliness have a significant effect on user satisfaction of Dukcapil Dalam Genggaman. Meanwhile, the format does not have a effect on user satisfaction of Dukcapil Dalam Genggaman. Based on these findings, the Department of Population and Civil Registration of Surakarta is recommended to develop Dukcapil Dalam Genggaman by focusing on the factors that affect user satisfaction of the application.

\section{Abstrak}

Electronic Government (e-Government) telah dilaksanakan di Indonesia baik di tingkat pusat maupun daerah, dimana Teknologi Informasi dan Komunikasi (TIK) diintegrasikan dengan pelayanan publik guna meningkatkan efektivitas, 
efisiensi dan transparansi. Kota Surakarta berhasil menciptakan sebuah aplikasi yang bergerak secara on line dimana dapat digunakan untuk mengakses pelayanan administrasi kependudukan, yaitu Dukcapil Dalam Genggaman. Aplikasi tersebut dirancang untuk memudahkan sebagian masyarakat Kota Surakarta yang masih mengalami kendala jika harus mengakses pelayanan administrasi kependudukan secara langsung, baik terkendala dalam hal waktu, tenaga maupun biaya. Sebagai bagian dari pelayanan administrasi kependudukan dan sistem informasi kependudukan, kepuasan pengguna menjadi hal yang penting bagi aplikasi Dukcapil Dalam Genggaman karena berkaitan dengan kualitas dari pelayanan yang diberikan dan keberhasilan dari penerapan aplikasi tersebut. Kepuasan pengguna dapat dipengaruhi oleh beberapa faktor. Oleh karena itu, penelitian ini akan meneliti faktor yang memengaruhi kepuasan pengguna aplikasi Dukcapil Dalam Genggaman. Faktor tersebut diadaptasi dari model pengukuran tingkat kepuasan pengguna sistem informasi, yaitu End User Computing Satisfaction (EUCS) yang mengukur kepuasan berdasarkan isi, akurasi, bentuk, kemudahan penggunaan dan ketepatan waktu. Penelitian ini bertujuan untuk mengetahui pengaruh dari faktor-faktor tersebut terhadap kepuasan pengguna aplikasi Dukcapil Dalam Genggaman. Kuesioner disebar secara kepada pengguna Aplikasi Dukcapil Dalam Genggaman dan berhasil mendapatkan sampel sebanyak 107 pengguna. Analisis data yang digunakan yaitu regresi linier berganda. Ditemukan bahwa isi, akurasi, kemudahan penggunaan dan ketepatan waktu memiliki pengaruh yang signifikan terhadap kepuasan pengguna aplikasi Dukcapil Dalam Genggaman. Sedangkan, bentuk tidak memiliki pengaruh terhadap kepuasan pengguna aplikasi Dukcapil Dalam Genggaman. Berdasarkan temuan tersebut, Dispendukcapil Kota Surakarta direkomendasikan untuk mengembangkan aplikasi Dukcapil Dalam Genggaman dengan berfokus pada faktor-faktor yang memengaruhi kepuasan pengguna aplikasi tersebut.

\section{Introduction}

Information and Communication Technology (ICT) has developed in the realm of Indonesian government. This development creates an integration between ICT and all forms of government activities, especially services to the public. Electronic Government (e-Government) is a government effort to integrate ICT advances with public services in order to improve service quality to be efficient, effective, transparent and accountable (Heeks, 2003; Indrajit, 2002; Suaedi, 2010).

Surakarta City Government is one of the local governments that has implemented Electronic Government (e-Government). Until 2018, the Surakarta City Government succeeded in creating an application that can be used to access online population administration services called Dukcapil application (Dukcapil dalam genggaman in indonesian term). This application is considered important considering that population administration services are one of the most needed public services for the people of Surakarta. It is proven that in the period 2016 to 2018, this service has been accessed 508,297 times and has increased every year. This creates a situation where the queue becomes long at certain times and sometimes people need to come more than once due to insufficient or incorrect conditions. Such a situation will be considered as an obstacle for some people who cannot leave their jobs. Reflecting on the existing constraints, the creation of the Dukcapil Dalam Handbook application is expected to save time, effort and costs because people only need to use their Android 
smartphone to access population administration services and one visit to the Department of Population and Civil Registration (Dispendukcapil) Surakarta City or the village office. them to retrieve the population documents that have been submitted. The exposure to the Corona Virus Disease (Covid-19) pandemic has made the existence of this application even more important after a policy emerged as of July 1, 2020 which states that all population administration services must be accessed online through the Dukcapil application with the aim of reducing crowds so that the chain of spread Covid-19 can be interrupted.

The Dukcapil application in your hand as a form of population administration service is basically created with the aim of getting satisfaction from its users. This is because a service can be declared successful if the service recipient is satisfied with the services provided (Ratminto \& Winarsih, 2007). Decree of the Minister of Administrative and Bureaucratic Reform (MenPAN-RB) Number 63 of 2003 concerning General Guidelines for the Implementation of Public Services also states that satisfaction is one of the standard measures in the implementation of public services so that a public service can be guaranteed certainty for service recipients, namely the community. The guarantee of certainty is a guarantee if the services provided are in accordance with what the community needs. Apart from that, satisfaction is also an important element in the delivery of public services along with elements of service providers, service recipients and types of services (Barata, 2014). The importance of user satisfaction for the sustainability of a service is generally due to user satisfaction which is closely related to the quality standards of the goods or services they have enjoyed. User satisfaction will also have an impact on user loyalty and loyalty, thus having a positive impact on the continuity of an organization (Budi \& Sumiari, 2017). Apart from playing a role as a form of population administration service, the Dukcapil application also has a role as part of a population information system. As part of the population information system, this application also still requires satisfaction from its users. This is because according to the model Information System Success (DEM IS Success) introduced by DeLone and McLean (2003), user satisfaction is one of the important factors that can determine the success of an information system. The emergence of policies requiring access to population administration services using the Dukcapil application further reinforces the importance of knowing user satisfaction from the application. This is because the application is the only access to use population administration services so that it can be said to be a vital application and has many users.

The satisfaction of an information system user can be influenced by several factors. These factors can be found in the measurement model of the user satisfaction level of the information system. One of the models is End User Computing Satisfaction (EUCS) which was introduced by Doll and Torkzadeh (1988). This model is an overall evaluation model of information system users based on their experience when using the information system. The evaluation that is carried out specifically emphasizes the satisfaction of end users by assessing the five variables in it, namely content, accuracy, format, ease of use and timeliness. Dalimunthe \& Ismiati (2016) successfully used this model to analyze the satisfaction of users of the Online Public Access Catalog (OPAC) at the UIN SUSKA Riau Library. This shows that the EUCS model can be used to 
analyze the satisfaction of an information system engaged in education. In addition, the EUCS model has also been used to examine user satisfaction in an information system engaged in trading, logistics and courier, health and banking (Damayanti, Mursityo, \& Herlambang, 2018; Munap, Ahmad, Hamid, \& Beg, 2018; Pauluzzo \& Geretto, 2018; Prasetyowati \& Kushartanti, 2018).

Therefore, this study will examine the factors that influence the satisfaction level of users of Dukcapil application in Surakarta. The End User Computing Satisfaction (EUCS) model will be used in this study by utilizing the variables in it to serve as a factor that may or may not have an influence on user satisfaction of the Dukcapil Dalam Grip application. This study aims to determine the effect of content, accuracy, form, ease of use and timeliness on the level of user satisfaction of the application.

\section{Literature Review}

\section{Model End User Computing Satisfaction (EUCS)}

End User Computing Satisfaction (EUCS) model is used to measure the satisfaction level of users of an application system by comparing the expectations and reality of an information system. EUCS is also defined as an overall evaluation model of information system users based on their experience in using the system (Doll \& Torkzadeh, 1988). The model developed by Doll \& Torkzadeh (1988) emphasizes end-user satisfaction by assessing content, accuracy, form, ease of use and timeliness of a information Systems. This model has been tested by other researchers to test its reliability and the results show no significant difference even though this instrument is translated into various different languages. 


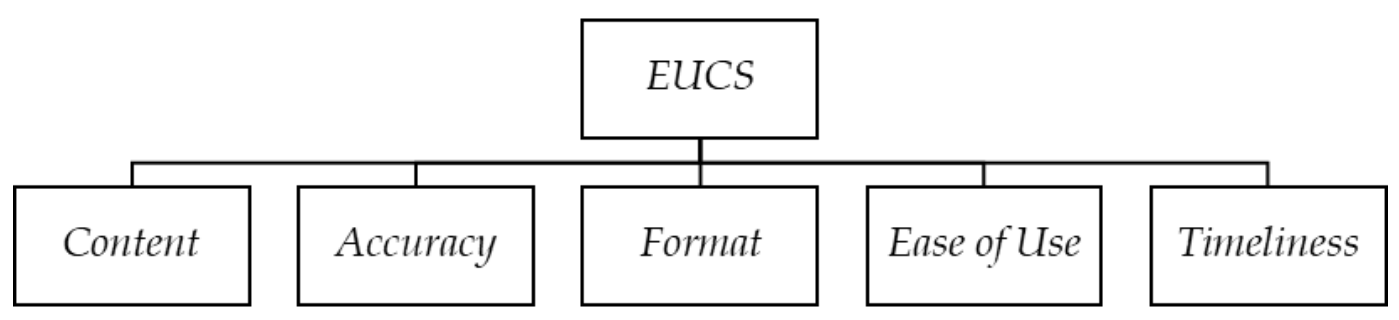

Source: Doll E Torkzadeh, 1988

Figure 1. Model End User Computing Satisfaction (EUCS).

\section{Content}

Content variables measure user satisfaction in terms of the content of a system. The contents of the system are usually functions and modules that can be used by system users and also information generated by the system (Dalimunthe \& Ismiati, 2016). This variable also measures whether the system produces information according to user needs. The more complete the module and the informative system, the higher the level of user satisfaction.

\section{Accuracy}

The accuracy variable measures user satisfaction in terms of data accuracy when the system accepts input and then processes it into information (Dalimunthe \& Ismiati, 2016). The accuracy of the system is measured by seeing how often the system produces wrong output when processing input from users, besides that, it can also be seen how often there are errors or errors in the data processing.

\section{Format}

Shape variables measure user satisfaction in terms of appearance and aesthetics of the system interface whether it is attractive or not and the appearance of the system makes it easier for users to use the system so that it can indirectly affect the level of effectiveness of the user (Dalimunthe \& Ismiati, 2016).

\section{Ease of Use}

Ease of use variable measures user satisfaction in terms of user ease or user friendliness in using the system such as the process of entering data, processing data and finding the information needed (Dalimunthe \& Ismiati, 2016).

\section{Timeliness}

Timeliness variable measures user satisfaction in terms of timeliness of the system in presenting or providing data and information required by users (Dalimunthe \& Ismiati, 2016). A system that is on time can be categorized as a realtime system, meaning that every request or input made by the user will be immediately processed and the output will be displayed quickly without having to wait long.

\section{Framework}


The framework is a diagram depicting the flow of thought from the research to be carried out. The following is the framework for this research:

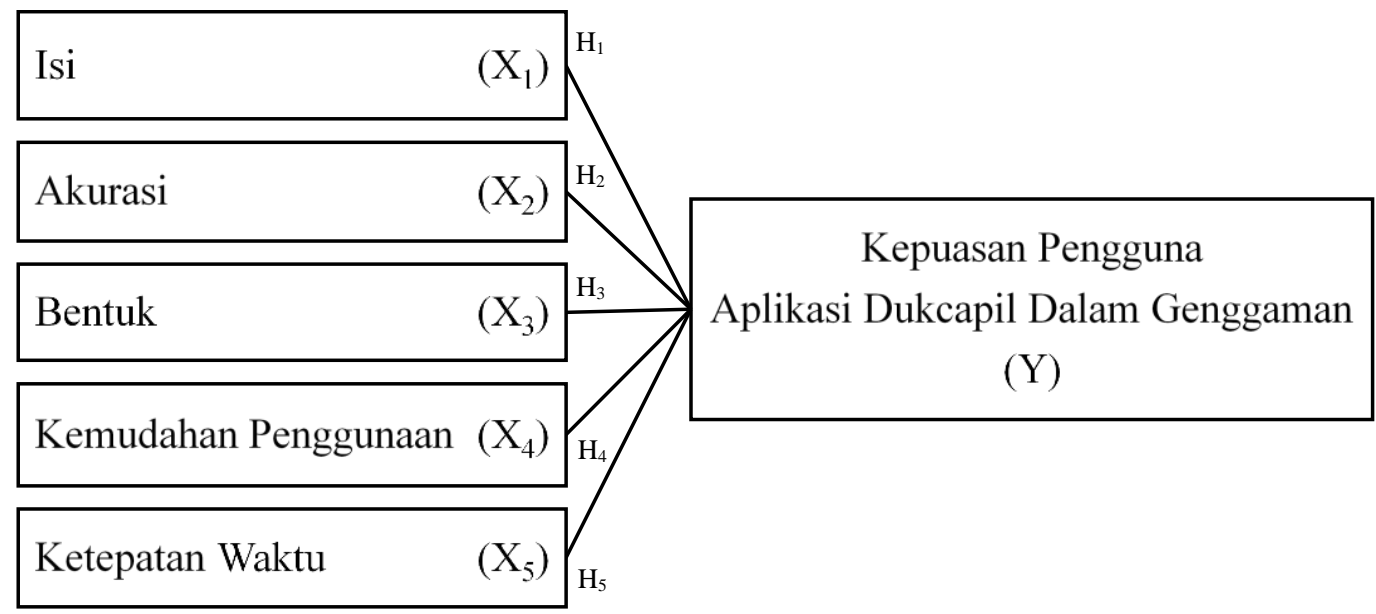

Figure 2. Framework

\section{Hypothesis}

$\mathrm{H}_{1}$ : There is a significant influence between content on user satisfaction of the Dukcapil application

$\mathrm{H}_{2}$ : There is a significant influence between accuracy and user satisfaction of the Dukcapil application

$\mathrm{H}_{3}$ : There is a significant influence between forms on user satisfaction of the Dukcapil application

$\mathrm{H}_{4}$ : There is a significant influence between ease of use on user satisfaction of the Dukcapil application

$\mathrm{H}_{5}$ : There is a significant influence between timeliness on user satisfaction of the Dukcapil application

\section{Researh Method}

This research is a quantitative study with an associative type combined with a survey method. The data collection technique used was a questionnaire with a scoring technique using a Likert scale to then be submitted to the respondent, namely the user of the Dukcapil application. Data collection will be carried out in person by visiting the urban village office in the city of Surakarta and online via Google Form. The kelurahan office was chosen because the population documents that have been submitted by users must still be taken at the respective kelurahan office and the Google Form is used to reach respondents who were not found when visiting the kelurahan office. The sampling technique used was accidental sampling where sampling was based on a coincidence. So that anyone who meets the researcher can be selected as a sample if that person is a good match (Sugiyono, 
2016). This technique is considered appropriate given the large population. So that a sample of 97 respondents was determined based on the results of the calculation with a significance level of 0.05 . Primary data in this study were obtained from respondents' answers through questionnaires and secondary data were obtained from the required documents. The independent variables $(X)$ in this study are content (X1), accuracy (X2), form (X3), ease of use (X4) and timeliness (X5). Meanwhile, the dependent variable $(Y)$ is the user satisfaction of the Dukcapil application.

\section{Instrument Test}

\section{Validity test}

The questionnaire instrument to be used needs to be tested first. The instrument test is divided into two (2) tests, namely the validity test and the reliability test. The validity test is used to test whether a questionnaire is valid or not. Valid instruments can be interpreted as measuring tools that can be used to obtain data. The validity test used is Pearson Product Moment. If rcount> rtable, then the instrument is said to be valid. Meanwhile, if rcount <rtabel, then the instrument is said to be invalid (Sugiyono, 2016).

\section{Reliability Test}

Reliability test is used to test the reliability of a questionnaire. A questionnaire is said to be reliable if the answers to the questions are consistent or stable over time (Ghozali, 2007). The reliability test used was Cronbach Alpha. If the Cronbach alpha value is $>0.600$, the instrument is said to be reliable. Meanwhile, if the Cronbach alpha value $<0.600$, then the instrument is said to be unreliable (Ghozali, 2007).

\section{Classic Assumption Test}

\section{Normality test}

After passing the instrument test, a questionnaire can be used to collect the required data. The data that has been collected first needs to pass the classical assumption test, which includes the normality test, linearity test and heteroscedasticity test. The classical assumption test is a condition that must be met before performing multiple linear regression. The test is needed in order to get the best regression results, which can be justified and not biased (Ghozali, 2011). The normality test is used to test whether the distribution of the dependent variable for each value of certain independent variables is normally distributed or not. The regression model can be said to be good if the data is normally distributed or close to normal, so it is feasible to carry out statistical testing. The normality test used is the Kolmogorov-Smirnov Test of Normality with a significance level (a) of 0.05 . If the probability value (asymtotic significance) $>\mathrm{a}$, then the distribution of the population is normal. Meanwhile, if the probability value (asymtotic significance) $<\mathrm{a}$, then the population is not normally distributed (Santoso, 2002). 


\section{Linearity Test}

Linearity test is used to determine whether the relationship is linear or not significant in the research variables (Prayitno, 2010). The linearity test used is the Test of Linearity. If the significance value $<\alpha$, then there is a linear relationship between the independent variable and the dependent variable. Meanwhile, if the significance value $>a$, then there is no linear relationship between the independent variable and the dependent variable (Ghozali, 2013).

\section{Heteroscedasticity Test}

The heteroscedasticity test is used to test whether the regression model has an inequality of variance from the residuals of one observation to another. A good regression model is one that has homoscedasticity or does not occur heteroscedasticity (Ghozali, 2013). The heteroscedasticity test used was the graph plot test between the predictive value of the dependent variable, namely ZPRED and its residual SRESID. Heteroscedasticity does not occur if there is no clear pattern and the dots spread above and below 0 on the Y axis (Ghozali, 2011).

\section{Multiple Linear Regression}

After passing the classical assumption test, the data obtained can be used to perform multiple linear regression. Multiple linear regression is carried out to analyze the magnitude of the relationship and the influence of the independent variables which are more than two (2) (Suharyadi \& Purwanto, 2004). Given that multiple linear regression requires data with an interval scale, while the data obtained from questionnaires with a Likert scale is an ordinal scale, a conversion process is needed to convert ordinal data into intervals using the Method of Successive Interval (MSI) developed by Hays (1976). This method will be accessed through the Microsoft Office Excel 2019 program. The results of multiple linear regression can be used to test the hypothesis and test the coefficient of determination (R2).

\section{Hypothesis Testing \\ F Test (Simultaneous Test)}

Hypothesis testing is divided into two tests, namely the $\mathrm{F}$ test and the $\mathrm{t}$ test. The $\mathrm{F}$ test is used to determine the effect of all independent variables in the model simultaneously (simultaneously) on the dependent variable. If Fcount $<$ Ftable or significance value $>\mathrm{a}$, then $\mathrm{H} 0$ is accepted and Ha is rejected. Meanwhile, if Fcount $\geq$ Ftable or a significance value $<\mathrm{a}$, then $\mathrm{H} 0$ is rejected and $\mathrm{Ha}$ is accepted. 


\section{T test (partial test)}

The $t$ test is used to determine the significance of the influence between the independent variables on the dependent variable partially. If tcount $\leq$ ttable or significance value $>\mathrm{a}$, then $\mathrm{H} 0$ is accepted and Ha is rejected. Meanwhile, if tcount $\geq$ ttable or the significance value $<\mathrm{a}$, then $\mathrm{HO}$ is rejected and Ha is accepted. This study has a t-table value of 1,660 . If there is acceptance of $\mathrm{H} 0$, it can be concluded that there is no significant influence between the independent variables and the dependent variable partially. Meanwhile, if $\mathrm{H} 0$ is rejected, it means that there is a significant influence between the independent variables on the dependent variable partially.

\section{Determination Coefficient Test (R2)}

The coefficient of determination (R2) test is carried out to measure the ability of a model to explain variations in the independent variable (Ghozali, 2013). R2 values range from zero to one. If the value of $\mathrm{R} 2$ approaches the number one, it can be said that the independent variable used is able to explain the variation in the dependent variable. Meanwhile, if the R2 value is close to zero, it can be said that the independent variable used is unable to explain the variation in the dependent variable. This study will use the adjusted R2 value because the adjusted R2 value can go up or down if one independent variable is added to the model (Ghozali, 2013). In addition, the $R 2$ value is not used in this study because every time there is an addition of an independent variable, the $R 2$ value will certainly increase regardless of whether the independent variable has a significant effect on the dependent variable or not.

\section{Results and Discussion}

As many as 120 questionnaires have been successfully submitted to respondents, namely users of the Dukcapil application directly by visiting the research location, namely all urban village offices in Surakarta, as many as 99 questionnaires and online using Google Form as many as 21 questionnaires. A total of 13 questionnaires had to be deleted due to several factors that appeared at the time of submission of the questionnaires in person or on line. The factors that emerged at the time of direct submission of the questionnaires were that some questionnaires were not filled in completely. Meanwhile, the factors that emerged at the time of submitting the questionnaire online included some respondents who claimed not to know and had never used the application and some respondents who were not Surakarta residents which meant they were not users of the Dukcapil application. So that in the end, we left 107 questionnaires to be processed with details of 91 questionnaires that were obtained directly and 16 questionnaires that were obtained online. The following are the characteristics of the 107 respondents based on gender, age, type of work, latest education, duration of use, time of use and type of service: 
Volume 6 No. 2, Desember 2020

pISSN: 2460-6162. eISSN: 2527-6476

Table 1. Respondent Characteristics

\begin{tabular}{|c|c|c|c|}
\hline \multirow[t]{2}{*}{ Gender } & Male & 56 & \multirow{2}{*}{ Total : 107} \\
\hline & Female & 51 & \\
\hline \multirow[t]{5}{*}{ Age } & $\leq 20$ years & 3 & \multirow{5}{*}{ Total: 107} \\
\hline & 21-30 Years & 47 & \\
\hline & 31-40 Years & 19 & \\
\hline & $41-50$ years & 16 & \\
\hline & $>50$ Years & 22 & \\
\hline \multirow[t]{5}{*}{ Occupation } & Student / Student & 17 & \multirow{5}{*}{ Total: 107} \\
\hline & Entrepreneur & 15 & \\
\hline & Government employees & 17 & \\
\hline & Private employees & 23 & \\
\hline & Etc & 35 & \\
\hline \multirow[t]{4}{*}{ Latest education } & Senior high school & 57 & \multirow{4}{*}{ Total: 107} \\
\hline & Bachelor & 38 & \\
\hline & Master & 7 & \\
\hline & etc & 5 & \\
\hline \multirow[t]{2}{*}{ Duration of Use } & 1 time & 26 & \multirow{2}{*}{ Total: 107} \\
\hline & $>1$ time & 81 & \\
\hline \multirow[t]{2}{*}{ Time of Use } & $\leq 1$ Year & 96 & \multirow{2}{*}{ Total: 107} \\
\hline & $>1$ Year & 11 & \\
\hline \multirow[t]{11}{*}{ Kind of service } & Reporting Registration & 50 & \multirow{11}{*}{ Total: 107} \\
\hline & Death Certificate & 12 & \\
\hline & Birth certificate & 19 & \\
\hline & Electronic KTP & 44 & \\
\hline & Child Identity Card (KIA) & 12 & \\
\hline & Family card & 49 & \\
\hline & Move Out & 9 & \\
\hline & Arrival & 8 & \\
\hline & Update Data & 32 & \\
\hline & Check Electronic ID Data & 25 & \\
\hline & Other Services & 5 & \\
\hline
\end{tabular}

Source: Primary data processed, 2020 


\section{Instrument Test Results}

\section{Validity Test Results}

Respondents as many as 35 users of the Dukcapil application have been successfully obtained to test the validity of the 23 instruments in the questionnaire. The following are the results of the validity test:

Table 2. Validity Test Results

\begin{tabular}{|c|c|c|c|}
\hline Code & rcount & rtable & Information \\
\hline CON1 & 0.757 & 0.334 & Valid \\
\hline CON2 & 0.744 & 0.334 & Valid \\
\hline CON3 & 0.782 & 0.334 & Valid \\
\hline CON4 & 0.617 & 0.334 & Valid \\
\hline ACC1 & 0.697 & 0.334 & Valid \\
\hline ACC2 & 0.537 & 0.334 & Valid \\
\hline ACC 3 & 0.601 & 0.334 & Valid \\
\hline ACC4 & 0.836 & 0.334 & Valid \\
\hline FOR1 & 0.801 & 0.334 & Valid \\
\hline FOR2 & 0.750 & 0.334 & Valid \\
\hline FOR3 & 0.669 & 0.334 & Valid \\
\hline FOR4 & 0.782 & 0.334 & Valid \\
\hline EOU1 & 0.806 & 0.334 & Valid \\
\hline EOU2 & 0.635 & 0.334 & Valid \\
\hline EOU3 & 0.694 & 0.334 & Valid \\
\hline EOU4 & 0.781 & 0.334 & Valid \\
\hline TIM1 & 0.791 & 0.334 & Valid \\
\hline TIM2 & 0.676 & 0.334 & Valid \\
\hline TIM3 & 0.859 & 0.334 & Valid \\
\hline US1 & 0.670 & 0.334 & Valid \\
\hline US2 & 0.831 & 0.334 & Valid \\
\hline US3 & 0.874 & 0.334 & Valid \\
\hline US4 & 0.705 & 0.334 & Valid \\
\hline
\end{tabular}

Source: Primary data processed, 2020

Based on Table 2, the overall instrument used in this study can be said to be valid. So, it can be concluded that 23 instruments can be used for further tests. 


\section{Reliability Test Results}

Instruments that have been declared valid will then pass the reliability test to determine whether the instrument is reliable. The following are the results of the reliability test:

Table 3. Reliability Test Results

\begin{tabular}{lccc}
\hline \multicolumn{1}{c}{ Variabel } & $\mathbf{r}_{\text {alpha }}$ & $\mathbf{r}_{\text {kritis }}$ & Information \\
\hline Isi & 0.713 & 0.600 & Reliable \\
Akurasi & 0.704 & 0.600 & Reliable \\
Bentuk & 0.741 & 0.600 & Reliable \\
Kemudahan Penggunaan & 0.724 & 0.600 & Reliable \\
Ketepatan Waktu & 0.699 & 0.600 & Reliable \\
Kepuasan Pengguna & 0.842 & 0.600 & Reliable \\
\hline
\end{tabular}

Source: Primary data processed, 2020

Based on Table 3, it can be observed that all variables have a Cronbach alpha value above 0.600 . So it can be concluded that all instruments in the six (6) variables used are declared reliable.

\section{Classical Assumption Test Results}

\section{Normality Test Results}

The normality test is used to test whether the distribution of the dependent variable for each value of certain independent variables is normally distributed or not. Following are the results of the normality test:

Table 4. Normality Test Results Test of Kolmogorov Smirnov

\begin{tabular}{|c|c|c|}
\hline & & Unstandardized Residual \\
\hline $\mathrm{N}$ & & 107 \\
\hline \multirow[t]{2}{*}{ Normal Parameters } & Mean & .0000000 \\
\hline & Std. Deviation & 1.89382888 \\
\hline \multirow[t]{3}{*}{ Most Extreme Differences } & Absolute & .044 \\
\hline & Positive & .037 \\
\hline & Negative & -.044 \\
\hline Kolmogorov-Smirnov Z & & .452 \\
\hline Asymp. Sig. (2-tailed) & & .987 \\
\hline
\end{tabular}

Source: Primary data processed, 2020

Based on Table 4, it can be observed that the probability (asymtotic significance) has a value of 0.987 . Therefore, it can be concluded that the distribution of the population is normal because the probability value (asymtotic significance) of 0.965 is stated to be greater than 0.05 . 


\section{Linearity Test Results}

Linearity test is used to determine whether the relationship is linear or not significant in the research variables (Prayitno, 2010). Here are the results of the linearity test:

Table 5. Linearity Test Results

\begin{tabular}{ll}
\hline & Sig. \\
\hline User Satisfaction * Content & .000 \\
User Satisfaction * Accuracy & .000 \\
User Satisfaction * Format & .000 \\
User Satisfaction * Ease of Use & .000 \\
User Satisfaction * Timeliness & .000 \\
\hline
\end{tabular}

Source: Primary data processed, 2020

Based on Table 5, it can be concluded that all independent variables have a linear relationship with the dependent variable because it has a significance value of 0.000 which is less than 0.05 .

\section{Heteroscedasticity Test Results}

The heteroscedasticity test is used to test whether the regression model used is an inequality of variance from the residuals of one observation to another. The following is a graph of the heteroscedasticity test:

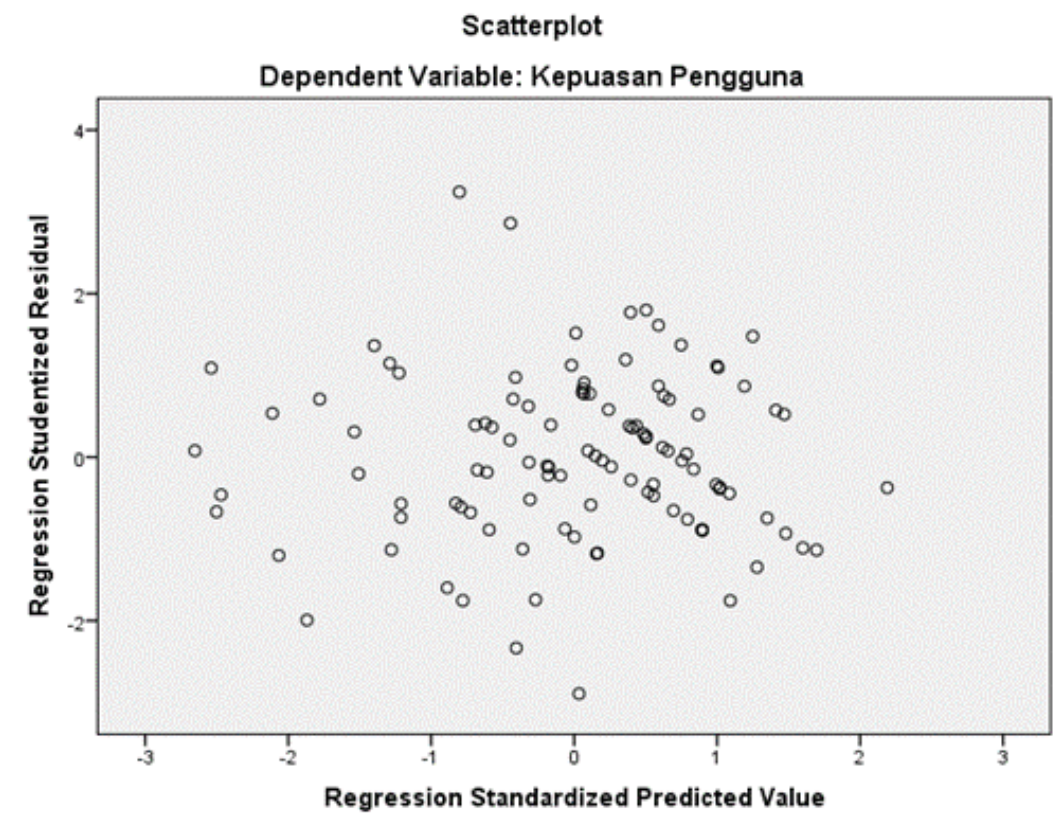

Source: Primary data processed, 2020

Figure 3. Heteroscedasticity Test Results 
Based on Figure 3, it can be observed that the points on the graph spread above and below the number 0 on the $\mathrm{Y}$ axis. Therefore, it can be concluded that heteroscedasticity does not occur and the regression is said to be good.

\section{Hypothesis Test Results}

\section{F Test Result (Simultaneous Test)}

The $\mathrm{F}$ test is used to determine the effect of all independent variables together (simultaneously) on the dependent variable. Following are the results of the F test:

Table 6. F Test Result (Simultaneous Test)

\begin{tabular}{|c|c|c|c|c|c|}
\hline & Sum of Squares & $\mathrm{df}$ & Mean Square & $\mathbf{F}$ & Sig. \\
\hline Regression & 560.853 & 5 & 112.171 & 29.800 & .000 \\
\hline Residual & 380.178 & 101 & 3.764 & & \\
\hline Total & 941.032 & 106 & & & \\
\hline
\end{tabular}

Source: Primary data processed, 2020

Based on Table 6, it can be observed that there is an Fcount value of 29,800 and a significance value of 0,000 . The basis for the first decision is to compare the value of Fcount with the value of Ftable. Thus, the Fcount value of 29,800 is greater than the Ftable value of 2.3. Furthermore, the basis for the second decision is to compare the significance value with the predetermined significance level value, namely 0.05 . Thus, the significance value of 0.000 is smaller than 0.05 . Based on the results of the decision making, it can be concluded that $\mathrm{HO}$ is rejected because all independent variables have a significant influence on user satisfaction of the Dukcapil Dalam Gengs application simultaneously.

\section{T test result (partial test)}

$\mathrm{T}$ test is used to determine the significance of the effect partially between the independent variables and the dependent variable. Here are the results of the $t$ test:

Table 7. T test result (partial test)

\begin{tabular}{lrrrrrr}
\hline & \multicolumn{2}{c}{$\begin{array}{c}\text { Unstandardized } \\
\text { Coefficients }\end{array}$} & \multicolumn{2}{c}{$\begin{array}{c}\text { Standardized } \\
\text { Coefficients }\end{array}$} & t & Sig. \\
\cline { 2 - 5 } (Constant) & B & \multicolumn{2}{c}{ Std. Error } & Beta & & \\
\cline { 2 - 5 } Isi & .012 & 1.208 & & .010 & .992 \\
Akurasi & .276 & .114 & & .246 & 2.434 & .017 \\
Bentuk & .218 & .106 & .208 & 2.052 & .043 \\
Kemudahan & .136 & .097 & .114 & 1.413 & .161 \\
Penggunaan & .191 & .088 & .187 & 2.167 & .033 \\
Ketepatan Waktu & .287 & .125 & & .190 & 2.294 & .024 \\
\hline
\end{tabular}

Source: Primary data processed, 2020 
Based on Table 6, it can be concluded that the variable content (X1), accuracy (X2), ease of use (X4) and timeliness (X5) have a partially significant effect on user satisfaction of the Dukcapil Dalam Grip application (Y). Meanwhile, the shape variable (X3) has no influence on user satisfaction of the Dukcapil in Hand $(\mathrm{Y})$ application.

\section{Result of Determination Coefficient Test (R2)}

The coefficient of determination (R2) test is carried out to measure the ability of a model to explain variations in the independent variable. (Ghozali, 2013) Following are the results of the determination coefficient test (R2):

Table 8. Result of Determination Coefficient Test (R2)

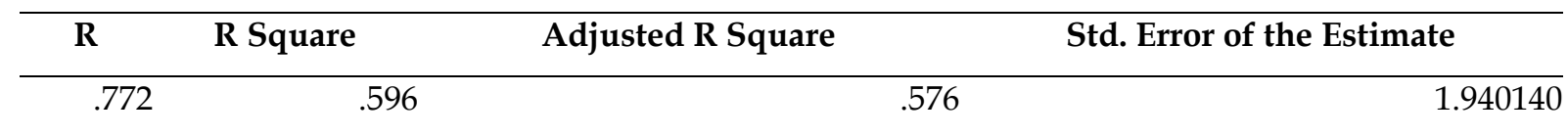

Source: Primary data processed, 2020

Based on Table 8, it can be observed that in this study, the variable content $(\mathrm{X} 1)$, accuracy $(\mathrm{X} 2)$, form (X3), ease of use (X4) and timeliness (X5) are used to explain the variable user satisfaction of the Dukcapil application in your hand ( $Y$ ) has an adjusted $\mathrm{R} 2$ value of 0.576 or $57.6 \%$, so that the remaining $42.4 \%$ is predicted by other variables outside the study.

\section{Results}

After passing the test for the proposed hypothesis, the following will show a summary of the results of hypothesis testing and discussion of each hypothesis.

Table 9. Summary of Hypothesis Test Results

\begin{tabular}{|c|c|c|c|}
\hline Hipotesis & Description & Variable & Results \\
\hline $\mathrm{H}_{1}$ & $\begin{array}{l}\text { Content has a significant effect on user } \\
\text { satisfaction of the Dukcapil application }\end{array}$ & $\mathrm{CON} \rightarrow \mathrm{US}$ & Accepted \\
\hline $\mathrm{H}_{2}$ & $\begin{array}{l}\text { Accuracy has a significant effect on user } \\
\text { satisfaction of the Dukcapil application }\end{array}$ & $\mathrm{ACC} \rightarrow \mathrm{US}$ & Accepted \\
\hline $\mathrm{H}_{3}$ & $\begin{array}{l}\text { Format has a significant effect on user } \\
\text { satisfaction of the Dukcapil application }\end{array}$ & $\mathrm{FOR} \rightarrow \mathrm{US}$ & Rejected \\
\hline $\mathrm{H}_{4}$ & $\begin{array}{l}\text { Ease of use has a significant effect on user } \\
\text { satisfaction of the Dukcapil application }\end{array}$ & $\mathrm{EOU} \rightarrow \mathrm{US}$ & Accepted \\
\hline $\mathrm{H}_{5}$ & $\begin{array}{l}\text { Timeliness has a significant effect on user } \\
\text { satisfaction of the Dukcapil application }\end{array}$ & $\mathrm{TIM} \rightarrow \mathrm{US}$ & Accepted \\
\hline
\end{tabular}

Source: Primary data processed, 2020

\section{Influence of Content on User Satisfaction of Dukcapil Application in Hand}


Based on the results of hypothesis testing in this study, the proposed H1 is acceptable. This means that the content has a significant effect on user satisfaction of the Dukcapil application. The existence of this significant effect is supported by the results of the $t$ test (partial test) for the content variable on the user satisfaction variable where the tcount value obtained is 2.434 greater than the $t$-table value of 1.660 and the significance value obtained is 0.017 less than 0.05 . The significant effect of content on user satisfaction of the Dukcapil application shows that the satisfaction of users of the application depends on the application's ability to provide complete population administration services, increase knowledge and benefit.

The Dukcapil application provides a new way of delivering administration services based on an application. The application should have population administration services that are as complete as population administration services that are accessed directly. This is further strengthened considering that the Dukcapil application is the only access in applying for population administration services during the Covid-19 pandemic. When the questionnaire data processing was carried out, there were still some input from users related to the completeness of the service. This input is the need for additional features such as a call center that is directly connected to the Surakarta Population and Civil Registration Service (Dispendukcapil) to make it easier for users when feeling confused or having problems. Another feature needed to support convenience for users is the ability of the Dukcapil application to serve submissions from several population administration services together so that users do not need to submit submissions one by one. Some users also need the refurbished requirement file repair feature so that users don't have to submit an initial submission when one of the required files is rejected. Improvements to the requirements file will also affect the userfriendliness of the application. The last feature suggested by users is that there are more choices for the type of extension for the required files to be uploaded. Until now, the Dukcapil application only accepts requirement files with a .jpg extension. This is an obstacle for some users considering the .jpg extension has a much larger size than other extensions such as .pdf. The requirement file with the .jpg extension results in an error that will appear during the upload process if the requirement file is too large.

For some users, the Dukcapil application is considered to be a new breakthrough in accessing population administration services. This breakthrough has made some users feel that using the Dukcapil application to access population administration services can improve their knowledge in accessing public services through an application on line. Therefore, some users feel that the application provides benefits both in terms of complete services and in terms of new knowledge gained. This research supports research that has been done previously by Anesa et al. (2017) where the content has a significant effect on user satisfaction of an information system. According to Anesa et al. (2017), It was revealed that e-Xamp user satisfaction depends on e-Xamp's ability to provide benefits in the form of complete, quality and available information when needed during computer-based school exams. The same is true for users of the Dukcapil application, where user 
satisfaction depends on the application's ability to provide complete, quality and useful services. However, there is one aspect that also affects user satisfaction of the Dukcapil application, namely the services provided can increase knowledge for users. The increase in knowledge is more aimed at new users in terms of accessing population administration services online via a smartphone device.

\section{The Effect of Accuracy on User Satisfaction of Dukcapil Applications}

Based on the results of hypothesis testing in this study, the proposed H2 is acceptable. This means that accuracy has a significant effect on user satisfaction of the Dukcapil application. The existence of this significant influence is supported by the results of the $t$ test (partial test) for the accuracy variable on the user satisfaction variable where the tcount value obtained is 2.052 greater than the $t$-table value of 1.660 and the significance value obtained is 0.043 smaller than 0.05 . The significant effect between accuracy and user satisfaction of the Dukcapil application shows that the satisfaction of users depends on the application's ability to provide population administration services accurately, rarely experiences errors and can be trusted.

Accurate is basically the alignment between input and output. If applied to the Dukcapil application, accurate can be interpreted as the harmony between the application for population administration services made by the user with the population documents obtained. Based on the results of the research, some users feel that the application is accurate in providing services so that users get the required population documents. The accuracy of the services provided by the application gives a sense of confidence to users to use the application when they want to apply for population administration services. However, some users still experience errors when using the application at night. This research supports research that has been done previously by Munap et al. (2018), where accuracy has a significant effect on user satisfaction of an information system. Munap et al. (2018) revealed that PRS user satisfaction depends on the PRS ability to provide reliable, accurate and error-free information. This aspect is also considered important for users of the Dukcapil application, where the population administration services provided must be reliable, accurate and free from errors during the submission process.

\section{Influence of Format on User Satisfaction of Dukcapil Application}

Based on the results of hypothesis testing in this study, the proposed H3 was rejected. This means that the form has no influence on user satisfaction of the Dukcapil application. The absence of this effect can be observed from the results of the $t$ test (partial test) for the form variable on the user satisfaction variable where the $t$-count value obtained is 1.413 smaller than the $t$-table value of 1.660 and the significance value obtained is 0.161 greater than 0.05 .

Format is defined as one of the variables that measures the satisfaction of users of information systems in terms of appearance and aesthetics of the system 
interface whether it is attractive or not, and the appearance of the system makes it easier for users to use the system (Dalimunthe \& Ismiati, 2016). The absence of influence between forms on user satisfaction of the Dukcapil application seems to contradict previous research conducted by Novita \& Ningsih (2020), which states that form has a significant effect on user satisfaction of an information system. According to Novita \& Ningsih (2020), e-Learning VILEP user satisfaction depends on the color, appearance and clarity of the e-Learning VILEP fonts. Meanwhile, user satisfaction of the Dukcapil application does not depend on the combination of colors, a neat layout, clear and legible letters and an attractive appearance of the application. Users of the application feel they are more concerned with the services provided by the application to be able to meet their needs in terms of complete, easy and fast management of population administration services.

\section{Effect of Ease of Use on User Satisfaction of the Dukcapil Application}

Based on the results of hypothesis testing in this study, the proposed $\mathrm{H} 4$ can be accepted. This means that ease of use has a significant effect on user satisfaction of the Dukcapil application. The existence of this significant influence is supported by the results of the $t$ test (partial test) for the ease-of-use variable on the user satisfaction variable where the tcount value obtained is 2.167 greater than the t-table value of 1.660 and the significance value obtained is 0.033 less than 0.05 . The significant influence between ease of use and user satisfaction of the application shows that the satisfaction of the user depends on the application's ability to pay attention to user-friendliness, provide user manuals, make users not need to take a long time to learn and easily to use.

The information system is essentially created to make it easier for users to access a job or need, so that if the system makes users feel difficult to use it can be said that the system is not successful (Suryawan \& Prihandoko, 2017). Thus, the Dukcapil application as a form of population administration information system needs to pay attention to convenience for its users. The results of the study have shown the same thing, where the attention of the application in terms of making it easier for users to be able to influence the decision to feel satisfied or not satisfied when using the application. The Dukcapil application needs to realize ease of use by regulating user-friendliness for its users and providing guidance on how to use it so that users feel the application is easy to use and doesn't take a long time to learn. However, there are still some users who find it difficult when using the application because it is the first time, they apply for population administration services through an application. Therefore, the results of this study support the research that has been done previously by Putra (2017) which states that ease of use has a significant effect on user satisfaction of an information system. Putra (2017) revealed that the ease of use of the Accrual Basis Agency System (SAIBA) is very important for the operator of the application for the work unit of the State Treasury Service Office (KPPN) type A1 as new users of SAIBA who are not experienced in using SAIBA. For users of the Dukcapil application, especially new users, the ease 
of using the application is also important so that users can learn the application quickly.

\section{Effect of Timeliness on User Satisfaction of Dukcapil Applications}

Based on the results of hypothesis testing in this study, the proposed $\mathrm{H} 5 \mathrm{can}$ be accepted. This means that timeliness has a significant effect on user satisfaction of the Dukcapil application. The existence of this significant influence is supported by the results of the $t$ test (partial test) for the timeliness variable on the user satisfaction variable where the tcount value obtained is 2,294 greater than the $t$-table value of 1,660 and the significance value obtained is 0.024 less than 0.05 . The existence of a significant influence between timeliness on user satisfaction of the application shows that the satisfaction of users depends on the application's ability to pay attention to the speed and timeliness of providing services as well as the ease of downloading so that users do not waste time just downloading the application.

Applications are defined as tools to simplify and speed up the work process (Ibisa, 2010). In line with this understanding, timeliness will certainly have a significant effect on user satisfaction of the Dukcapil application. As access to one of the many public services needed by the people of Surakarta, time is a big challenge for the Dukcapil application. In addition, considering the creation of the application, which is to answer complaints from the public regarding the long queues that often appear at the Surakata City Population and Civil Registration Service (Dispendukcapil) and input to create public services on line and provide a sense of security for the community by avoiding them from the crowd during the Covid-19 pandemic. However, there were still several complaints submitted by some users, where they felt that the data verification process was not correct at the specified time, which exceeded the three-day grace period. The results of this study support the upstream research that has been conducted by Munap et al. (2018), which reveals that timeliness has a significant effect on user satisfaction of an information system. Munap et al. (2018) revealed that the timeliness of providing information is very important for PRS users. Delay in information will lead to dissatisfaction with customers at the counter, so that it will also have an impact on the dissatisfaction of PRS users. The importance of punctuality is also considered important by users of the Dukcapil application, paticualrly in the case of timeliness of providing population administration services.

\section{Conclusion}

Based on the results of the research, it can be concluded that the user satisfaction of the Dukcapil application is influenced by several factors, including content, accuracy, ease of use and timeliness. The content has the most significant effect with a tcount of 2.434 and a significance value of 0.017 . Furthermore, followed sequentially starting from timeliness, ease of use and accuracy with tcount values of 2,294, 2,167 and 2,052 and significance values of $0.024,0.033$ and 0.043 . There is one factor that does not have a significant effect on user satisfaction of the 
application, namely format. This has no effect on user satisfaction of the Dukcapil application because it has a t-count value of 1.413 and a significance value of 0.161 .

Further research, which is similar to this research, is suggested to increase the sample size so that the generalization of the research is stronger and the preparation of questionnaires with more complete and in-depth instruments is also needed so that the data obtained can be more accurate. The Department of Population and Civil Registration (Dispendukcapil) of Surakarta is advised to hold a massive socialization for the people of Surakarta, pay more attention to the aspects of reliability and timeliness of the Dukcapil application and make additional features, including: (1) Call center; (2) Notification by e-mail and WhatsApp; (3) Repair of rejected requirements documents; (4) Submission of several services together; (5) Adding options for the type of file extension requirements that can be uploaded; (6) Procurement of Dukcapil in apps for iOS users.

\section{References}

Anesa, K., Zulhendra, \& Kurniadi, D. (2017). Analisa Kepuasan Pengguna Aplikasi E-XAMP Editor Sebagai Aplikasi Ujian Sekolah Berbasis Komputer di SMKN 3 Pariaman Menggunakan Metode End User Computer Satisfaction (EUCS) yang Diperluas. Jurnal Vokasional Teknik Elektronika Dan Informatika, 5(2), 83-88.

Barata, A. A. (2014). Dasar-Dasar Pelayanan Prima. Jakarta: Elex Media Komputindo.

Budi, I. G. K. T. P., \& Sumiari, N. K. (2017). Pengukuran Customer Satisfaction Index Terhadap Pelayanan di Century Gym. Jurnal Ilmiah Sisfotenika, 7(1), 25-37.

Dalimunthe, \& Ismiati. (2016). Analisis Tingkat Kepuasan Pengguna Online Public Access Catalog (OPAC) Dengan Metode EUCS (Studi Kasus: Perpustakaan UIN Suska Riau). Jurnal Rekayasa Dan Manajemen Sistem Informasi, 2(1), 71-75.

Damayanti, A. S., Mursityo, Y. T., \& Herlambang, A. D. (2018). Evaluasi Kepuasan Pengguna Aplikasi Tapp Market Menggunakan Metode EUCS (End User Computing Satisfaction). Jurnal Pengembangan Teknologi Informasi Dan Ilmu Komputer, 2(11), 4833-4839.

Doll, W. J., \& Torkzadeh, G. (1988). The Measurement of End-User Computing Satisfaction. MIS Quarterly.

Ghozali, I. (2007). Aplikasi Analisis Multivariate Dengan Program SPSS. Semarang: Badan Penerbit Universitas Diponegoro.

Ghozali, I. (2011). Aplikasi Analisis Mutivariate Dengan Program SPSS. Semarang: Badan Penerbit Universitas Diponegoro.

Ghozali, I. (2013). Aplikasi Analisis Multivariate Dengan Program IBM SPSS 21 Update PLS Regresi. Semarang: Badan Penerbit Universitas Diponegoro.

Heeks. (2003). Most E-Government for Developing Projects Fail How Can Risk be Reduces? Manchester: E-Government Working Paper Series.

Ibisa. (2010). Sistem Evaluasi dan Auditing Sistem Aplikasi Bagi Perusahaan. 
Yogyakarta: Andi Offset.

Indrajit, R. E. (2002). Membangun Aplikasi E-Government. Jakarta: Elex Media Komputindo.

Munap, R., Ahmad, S. N. B., Hamid, S. A., \& Beg, M. F. B. B. T. (2018). The Influence of End User Computing Satisfaction System (EUCS) on User Satisfaction The Case a Logistic and Courier Service Company. The International Jpurnal of Social Science and Humanities Invention, 5(12), 5103-5110.

Novita, D., \& Ningsih, D. S. (2020). Analisis Pengaruh Implementasi E-Learning Vilep di Poltekkes Kemenkes Palembang dengan Pendekatan EUCS. Jurnal Teknik Informatika Dan Sistem Informasi, 7(1), 29-41.

Pauluzzo, R., \& Geretto, E. F. (2018). Validating the EUCS Model to Measure the Level of Satisfaction of Internet Users in Local Banks in Italy. Journal of Organizational and End User Computing, 30(1), 66-81.

Prasetyowati, A., \& Kushartanti, R. (2018). User Satisfaction Analysis of Primary Care Information Systems in Semarang City with EUCS Model. Unnes Journal of Public Health, 7(2), 120-125.

Prayitno, D. (2010). Teknik Mudah dan Cepat Melakukan Analisis Data Penelitian Dengan SPSS dan Tanya Jawab Ujian Pendadaran. Yogyakarta: Gaya Media.

Putra, G. A. P. (2017). Analisis Faktor-Faktor yang Memengaruhi Kepuasan Pengguna Sistem Akuntansi Instansi Basis Akrual (SAIBA) Dengan Model End-User Computing Satisfaction. Jurnal Perbendaharaan, Keuangan Negara Dan Kebijakan Publik, 2(3), 33-42.

Ratminto, \& Winarsih. (2007). Manajemen Pelayanan. Yogyakarta: Pustaka Belajar.

Santoso, S. (2002). Konsep dan Aplikasi Dengan SPSS. Jakarta: Elex Media Komputindo.

Suaedi, F. D. (2010). Revitalisasi Administrasi Negara (Reformasi Birokrasi dan EGovernance). Yogyakarta: Graha Ilmu.

Sugiyono. (2016). Metode Penelitian Kuantitatif, Kualitatif dan RED. Bandung: PT. Alfabet.

Suharyadi, \& Purwanto. (2004). Metode Penelitian. Jakarta: Gramedia Pustaka Utama.

Suryawan, B. M., \& Prihandoko. (2017). Evaluasi Penerapan SIAKAD Politeknik Negeri Madiun Menggunakan Pendekatan TAM dan EUCS. Citee Journal, 4(3), 233-244. 